Abstract

\title{
Demand for Animal-Based Food Products and Sustainability ${ }^{\dagger}$
}

\section{Diana Bogueva * and Dora Marinova}

Citation: Bogueva, D., Marinova, D. Demand for Animal-Based Food Products and Sustainability.

Proceedings 2021, 73, 15. https://doi.org/ 10.3390/IECA2020-08817

Published: 2 December 2020

Publisher's Note: MDPI stays neutral with regard to jurisdictional claims in published maps and institutional affiliations.

Copyright: $₫ 2020$ by the authors. Licensee MDPI, Basel, Switzerland. This article is an open access article distributed under the terms and conditions of the Creative Commons Attribution (CC BY) license (http://creativecommons.org/licenses/by/4.0/).
Curtin University Sustainability Policy Institute, Curtin University, GPO Box U1987, Perth, WA 6845, Australia; d.marinova@curtin.edu.au

* Correspondence: diana.bogueva@graduate.curtin.edu.au

+ Presented at the 1st International Electronic Conference on Animals-Global Sustainability and Animals: Science, Ethics and Policy, 5-20 December 2020; Available online: https://ieca2020.sciforum.net/.

\begin{abstract}
The demand for animal-based food products is growing across the world, and many are consciously consuming a protein-rich diet. However, the growing consumption of animal proteins contradicts the Earth's ability to sustainably feed its population. Curbing emissions from agriculture, and especially from livestock production, is essential to fulfilling the Paris Agreement and shifting to a different diet, including EAT-Lancet's Planetary Health Diet, the flexitarian diet, and other ethically based dietary choices. Consuming modest or lower amounts of meat is viewed as one of the ways toward achieving sustainability. An increased focus on plant-based foods and other meat alternatives presents a strong potential for reducing agriculture-induced emissions and transitioning towards a more plant-based agricultural sector and underlines the need for worldwide national policies incentivizing this transition. The presentation explores whether consumers are ready to shift to a diet that is better for their health and that of the natural environment.
\end{abstract}

Keywords: animal proteins; plant-based food; cultured meat; insect; algae; sustainability

Supplementary Materials: The following are available online at https://sciforum.net/conference/ IECA2020/keynote/1804210b099f73bb2936d5af9a3c3b3e/presentation_video/GMT20201130-215352_ Diana-Bogueva-s-Zoom-Meeting_1920x1080.mp4.

Author Contributions: All equal contribution. All authors have read and agreed to the published version of the manuscript.

Institutional Review Board Statement: The study was approved by the Human Research Ethics Committee at Curtin University.

Informed Consent Statement: Not applicable.

Data Availability Statement: Data is content within the article. 